\title{
Kinetics of secretion of recombinant acid phosphatase by Myxococcus xanthus: a sensitive probe for the assay of protein translocation through the envelopes
}

\author{
Barbara Letouvet-Pawlak, Sylvie Barray, Karine Laval-Favre \\ and JANINE F. GUESPIN-MICHEL* \\ Equipe de Génétique Bactérienne, URA 203 CNRS, Faculté des Sciences de Rouen, \\ 76821 Mont-Saint-Aignan Cedex, France
}

(Received 11 November 1992; revised 27 July 1993; accepted 9 September 1993)

\begin{abstract}
The gene encoding a periplasmic pH 2.5 acid phosphatase (appA) from Escherichia coli was placed under the control of an inducible promoter and integrated into the chromosome of Myxococcus xanthus. The majority of the AppA protein synthesized in $M$. xanthus accumulated in the periplasm whereas about $30 \%$ was secreted into the medium. The kinetics of AppA secretion through the 'outer envelopes' (i.e. periplasm + outer membrane) were followed after AppA induction. The results suggest that AppA crosses these envelopes by a mechanism involving diffusion and show that the periplasmic accumulation of AppA and envelope permeability are decreased by mutations that decrease the secretion of native proteins in $M$. xanthus.
\end{abstract}

\section{Introduction}

Myxococcus xanthus is a Gram-negative scavenging bacterium that belongs to the myxobacteria. To feed upon other micro-organisms, these bacteria secrete numerous hydrolytic enzymes during exponential growth (Rosenberg \& Varon, 1984), and also during a multicellular developmental cycle characteristic of this family that leads to the formation of fruiting bodies (Shimkets, 1989). Under laboratory growth conditions, up to 50 different secreted proteins have been distinguished by electrofocusing of the culture medium of strain DK101 (Nicaud et al., 1984).

Previous studies have shown that the secretory mechanism in $M$. xanthus does not have the same high degree of specificity as the secretory systems found in other Gram-negative species (for review see Pugsley, 1988, 1993; Hirst \& Welch, 1988; Letouvet-Pawlak, $1991 b$ ) with the exception of the leakage process induced by the colicin lysis protein in Escherichia coli (Baty et al., 1987). For example, Erwinia chrysanthemi pectate lyases can be secreted from a recombinant $M$. xanthus strain (Breton et al., 1986), although they are not secreted by a recombinant strain of a closely related species, Erwinia carotovora subsp. carotovora (He et al., 1991). Fur-

* Author for correspondence. Tel. +333514 66 84; fax +333514 7020. thermore, the TEM1 $\beta$-lactamase as well as the E. coli pH 2.5 acid phosphatase, both of which are normally periplasmic enzymes, are partially released from recombinant $M$. xanthus (Breton \& Guespin-Michel, 1987). Nonetheless, it is presumed that protein secretion in $M$. xanthus occurs by a two-step mechanism involving export of proteins into the periplasm, followed by their secretion through the outer membrane. The foreign proteins that have been expressed and secreted by $M$. xanthus are all synthesized as precursors with a signal peptide (Breton et al., 1986; Breton \& Guespin-Michel, 1987). One additional argument in favour of the requirement for a signal peptide in protein secretion by $M$. xanthus proceeds from the fact that TnphoA (Manoil $\&$ Beckwith, 1985) random insertions yield chimeric proteins displaying phosphatase activity, some of which are extracellular (Kalos \& Zissler, 1990; Breton et al., 1990).

On the other hand, transposon insertion mutants, designated $\mathrm{Exc}^{ \pm}$, have been obtained (Nicaud et al., 1984) that display a decrease in the amount of most extracellular proteins, as well as slime (Masson \& Guespin-Michel, 1988), with no evidence of protein accumulation in the periplasm, in contrast to what was shown in Pseudomonas aeruginosa (Wretlind \& Pavlovskis, 1984), Aeromonas hydrophila (Howard \& Buckley, 1983) or E. chrysanthemi (Andro et al., 1984; Thurn \& Chatterjee, 1985). 
These $\operatorname{Exc}^{ \pm}$mutants display several unusual properties: (i) most of the extracellular enzymic activities assayed thus far are decreased, as is the total amount of secreted protein, but the protein patterns obtained by electrofocusing culture supernatants differ only slightly from those of the parental Exc ${ }^{+}$strain (Nicaud et al., 1984); (ii) mutations leading to this phenotype belong to several unlinked loci and prevent fruiting body formation, which suggests a relationship between protein secretion and development (Petit et al., 1993); (iii) the production of foreign $\mathrm{pH} 2.5$ acid phosphatase is also impaired by $\mathrm{Exc}^{ \pm}$mutations which decrease both cellbound and extracellular activities (Breton \& GuespinMichel, 1987). This shows that these $\operatorname{Exc}^{ \pm}$mutations impair genes that regulate the production of extracellular proteins at a post-transcriptional level, for instance at the level of export or secretion. However, a more precise analysis of the two steps involved in protein secretion, i.e. export and outer envelope translocation, is necessary.

To carry out this analysis, we took advantage of the fact that E. coli $\mathrm{pH} 2.5$ acid phosphatase is only partly secreted [whereas most native proteins have not been detected in the periplasm (Nicaud et al., 1984)]. The app $A$ gene that encodes this protein was cloned under the control of the IPTG-inducible tac promoter and introduced in the chromosome of different strains of $M$. xanthus.

We showed that secretion of the AppA protein by $M$. xanthus can be quantified by two parameters that reflect the permeability of the outer envelopes toward this protein and that an $\mathrm{Exc}^{ \pm}$mutation yields both a decrease in outer membrane permeability and a decrease in the quantity of the foreign protein in the periplasm.

\section{Methods}

Bacterial strains, plasmids and phages. These are listed in Table 1.

Media. M. xanthus was grown in CTT medium at $30^{\circ} \mathrm{C}$ (Bretscher \& Kaiser, 1978). E. coli was grown in LB medium (Miller, 1972) at $37^{\circ} \mathrm{C}$. Media were solidified with $1.2 \%(\mathrm{w} / \mathrm{v})$ agar when necessary.

Plasmid construction and cloning. T4 DNA ligase and restriction enzymes were obtained from Boehringer Mannheim. All enzymes were used according to the specifications of the manufacturer. The ligation was performed overnight at $16{ }^{\circ} \mathrm{C}$. Plasmid DNA was isolated from host bacteria as described by Holmes \& Quigley (1981) for plasmids smaller than $15 \mathrm{~kb}$, and according to Birnboim \& Doly (1979) for plasmids larger than $15 \mathrm{~kb}$. Transformations were performed using calcium chloride as described by Dagert \& Ehrlich (1974). Cells used in transformations (E. coli strain DH5 $\alpha \mathrm{MCR}$ ) were diluted into $1 \mathrm{ml} \mathrm{LB}$ medium after heat shock and grown for $1 \mathrm{~h}$ at $37^{\circ} \mathrm{C}$ before being plated on to selective medium containing ampicillin $\left(500 \mu \mathrm{g} \mathrm{ml}^{-1}\right)$.

Construction of a cointegrate for appA transfer into $M$. xanthus. pME472 is a conjugative IncP plasmid in which two tandemly repeated IS21 elements allow the formation of cointegrates with other plasmids. pGM589 is a cointegrate obtained according to Breton \& GuespinMichel (1987), between pME472 and the recombinant plasmid
pGM588, which can be transferred by conjugation from the $E$. coli donor to $M$. xanthus.

In vivo gene transfer procedures.

(i) Matings. Filter matings were performed overnight as described previously (Breton et al., 1985). M. xanthus transconjugants were selected for their resistance to kanamycin $\left(75 \mu \mathrm{g} \mathrm{ml}^{-1}\right)$.

(ii) Transduction of Tn5 insertion $\Omega 031$ from strain CM031 to strain CM243. Strain CM243 was transduced with $\mathrm{Mx} 4^{\text {ts }}$ lysate grown on CM031 according to Campos et al. (1978). The transductants were selected by the Tn5-borne resistance to phleomycin (Saulnier et al., 1988). The transductants were $\mathrm{Exc}^{ \pm}$and $\mathrm{Fru}^{-}$, and had retained the other characteristics of CM243. Clone CM245 was retained.

pH 2.5 acid phosphatase detection on plates. The method was developed for $E$. coli by Boquet et al. (1987): the pH 2.5 acid phosphatase (Dassa \& Boquet, 1985) activity was revealed by using $p$ nitrophenyl phosphate (PNPP) as substrate at $37^{\circ} \mathrm{C}, \mathrm{pH} 2 \cdot 5$. Yellow haloes of $p$-nitrophenol (PNP) surround the $\mathrm{App}^{+}$clones.

The above method was adapted for use in $M$. xanthus by Breton $\&$ Guespin-Michel (1987). The App ${ }^{+}$clones displayed a yellow colour which could only be seen on tan colonies.

Enzyme assays. Cells and supernatant were separated by centrifugation for $5 \mathrm{~min}$ in a microfuge.

(i) $p H 2.5$ acid phosphatase. The assays were performed according to Dassa \& Boquet (1981) with PNPP as substrate. One unit of enzyme

Table 1. Strains, plasmids and phages

\begin{tabular}{|c|c|c|}
\hline & Relevant characteristics & References \\
\hline \multicolumn{3}{|l|}{ Strains } \\
\hline \multicolumn{3}{|l|}{ E. coli } \\
\hline DH $5 \alpha \mathrm{MCR}$ & $\begin{array}{l}\text { recAl mcrA mcrB hsdR } \\
\text { endAI }\end{array}$ & Hanahan (1983) \\
\hline W3101 Nal ${ }^{\mathrm{r}}$ & $\operatorname{recAl} \operatorname{Tr} y^{-} \mathrm{Nal}^{\mathrm{r}}$ & $\begin{array}{l}\text { Kopecko et al. } \\
(1976)\end{array}$ \\
\hline $\mathrm{C} 600$ & $\begin{array}{l}\text { thil thr1 leuB6 lacY1 tonA1 } \\
\text { supE44 }\end{array}$ & Appleyard (1954) \\
\hline \multicolumn{3}{|l|}{ M. xanthus } \\
\hline DK1622 & Wild type, yellow & Kaiser (1979) \\
\hline DK101 & Yellow, $\mathrm{Fru}^{+}, \mathrm{Mot}^{ \pm}, \mathrm{Exc}^{+}$ & $\begin{array}{l}\text { Hodgkin \& Kaiser } \\
\text { (1979) }\end{array}$ \\
\hline DZ1 & Tan, $\mathrm{Fru}^{-}, \mathrm{Mot}^{-}, \mathrm{Exc}^{ \pm}, \mathrm{Str}^{\mathrm{r}}$ & $\underset{(1978)}{\text { Zusman et al. }}$ \\
\hline CM240 & DK1622 $\operatorname{Str}^{\mathrm{r}}$ & This work \\
\hline CM031 & $\begin{array}{l}\text { DK101::Tn5 Exc }{ }^{ \pm} \mathrm{Fru}^{-} \\
\text {Tan }\end{array}$ & Nicaud et al. (1984) \\
\hline CM2214 & DZ1::pGM589 & This work \\
\hline CM2217 & $\mathrm{DZ1}::$ pGM $589^{*}$ & This work \\
\hline CM2216 & $\mathrm{DZ1}::\left(\operatorname{app} A \operatorname{lac} Z \mathrm{Km}^{\mathrm{r}}\right)$ & $\begin{array}{l}\text { Letouvet-Pawlak } \\
\quad(1991 a)\end{array}$ \\
\hline CM243 & CM240::pGM589* & This work \\
\hline CM245 & CM243::Tn5 $(\Omega 031)$ & This work \\
\hline \multicolumn{3}{|l|}{ Plasmids } \\
\hline pTTQ18 & $\mathrm{Ap}^{\mathrm{r}}, l a c I^{\mathrm{q}}, p^{t a c}$, polylinker & Stark (1987) \\
\hline pME472 & IncP, $\mathrm{Km}^{\mathrm{r}}, \mathrm{Tc}^{\mathrm{r}}, \mathrm{Ap}^{\mathrm{s}}, 2$ IS 21 & $\begin{array}{l}\text { Reimmann et al. } \\
\text { (1988) }\end{array}$ \\
\hline pGM588 & pTTQ18::appA & This work \\
\hline pGM589 & pGM588::pME472 & This work \\
\hline pGM $589^{*}$ & $\begin{array}{l}\text { pGM589 retransferred from } \\
\text { GM589 (HFI) }\end{array}$ & This work \\
\hline pPB1132 & $\mathrm{pBR} 322:: a p p A \mathrm{Tc}^{\mathrm{s}}, \mathrm{Ap}^{\mathrm{r}}$ & Boquet et al. (1987) \\
\hline \multicolumn{3}{|l|}{ Bacteriophages } \\
\hline $\mathrm{Mx} 4^{\text {ts }} \mathrm{hrm}$ & $\begin{array}{l}\text { Transduction phage from } M \text {. } \\
\text { xanthus }\end{array}$ & $\begin{array}{l}\text { Campos et al. } \\
(1978)\end{array}$ \\
\hline
\end{tabular}




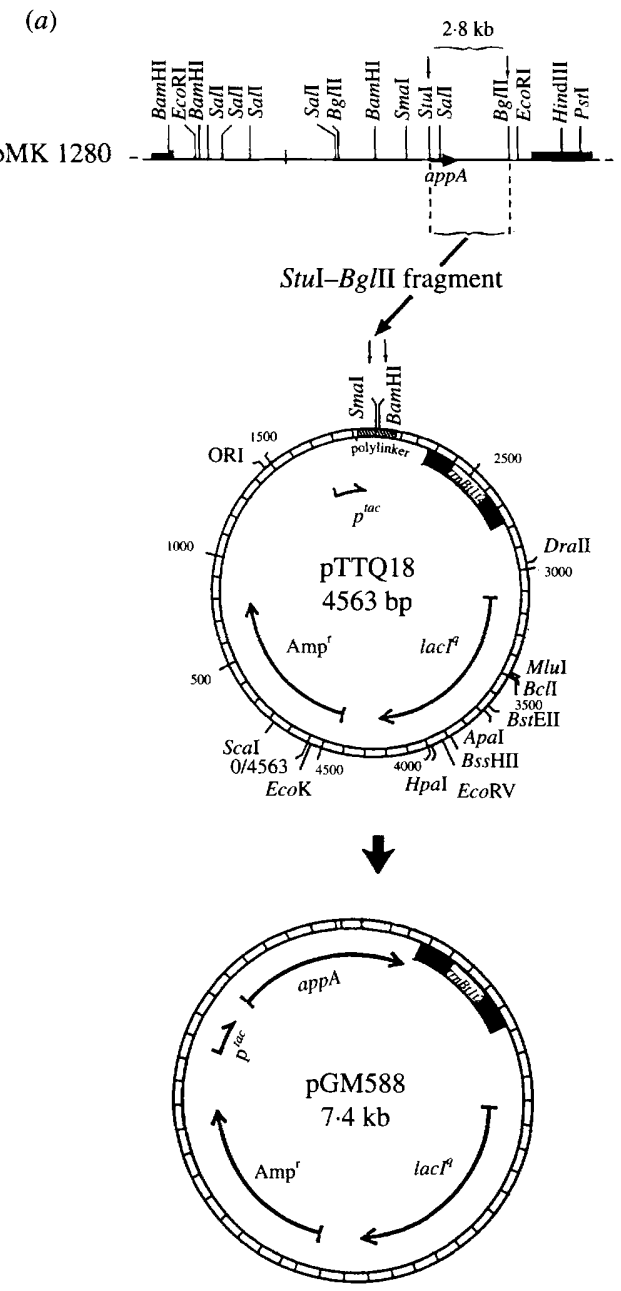

corresponds to the amount of enzyme which produces $1 \mathrm{nmol}$ PNP $\min ^{-1}$ at $37^{\circ} \mathrm{C}, \mathrm{pH} 2.5$. The molar extinction coefficient of PNP, measured under the assay conditions, is $1.78 \times 10^{4} \mathrm{M}^{-1} \mathrm{~cm}^{-1}$ at $410 \mathrm{~nm}$ (the spontaneous hydrolysis of PNPP was routinely assayed and subtracted from our values).

(ii) $\beta$-Galactosidase. The assays were performed on cells and supernatant by the procedure of Miller (1972) using $O$-nitrophenyl- $\beta$ D-galactopyranoside (ONPG) as substrate. One unit of $\beta$-galactosidase was defined as the amount of enzyme producing $1 \mathrm{nmol} O$-nitrophenol (ONP) $\min ^{-1}$ at $28^{\circ} \mathrm{C}, \mathrm{pH} 7$.

(iii) Proteolytic activity. The total proteolytic activity was assayed in the supernatant at $\mathrm{pH} 9 \cdot 6$ with azocasein as substrate (Millet, 1970).

Cell fractionation in $M$. xanthus. We used the cell fractionation procedure of Hartzell \& Kaiser (1991) with some modifications. Liquid-grown cultures of the $M$. xanthus CM2216, a recombinant strain producing both $\beta$-galactosidase (used as cytoplasmic marker) and $\mathrm{pH} 2.5$ acid phosphatase, were harvested at a cell density of $4 \times 10^{8}$ cells ml ${ }^{-1}$ and centrifuged at $8000 \mathrm{~g}$ for $10 \mathrm{~min}$ at $15^{\circ} \mathrm{C}$. The cells were washed in 1 vol. cold $50 \mathrm{~mm}$-Tris ( $\mathrm{pH} \mathrm{7.5)}$ and centrifuged at $16000 \mathrm{~g}$ for $15 \mathrm{~min}$ at $5{ }^{\circ} \mathrm{C}$. The supernatant was designated the 'Tris fraction'. The pellet was suspended in 0.25 vols cold $0.75 \mathrm{M}$-sucrose $/ 10 \mathrm{~mm}$-Trisacetate ( $\mathrm{pH} 7 \cdot 9)$. Lysozyme and EDTA were added to final concentrations of $2 \mathrm{mg} \mathrm{ml}^{-1}$ and $0.5 \mathrm{mM}$, respectively. The reaction was incubated on ice for at least $1 \mathrm{~h}$ and then centrifuged at $21000 \mathrm{~g}$ for $10 \mathrm{~min}$ at $5{ }^{\circ} \mathrm{C}$. The supernatant, containing part of the periplasm, was retained and named the 'PI fraction'. For the enzymic assays, a dilution of the PI fraction was required because EDTA inhibits a large part of the $\beta$ galactosidase activity and, to a lesser extent, the acid phosphatase activity. The pellet was suspended in 2 vols cold $0 \cdot 1 \mathrm{M}$-sucrose $/ 10 \mathrm{~mm}$ Tris-acetate ( $\mathrm{pH} 7.9)$ and incubated on ice. After $2 \mathrm{~h}$, most of the cells had formed spheroplasts. However $5-6 \%$ of the cells in the suspension were still intact bacilli as estimated by microscopic examination. The preparation was centrifuged at $16000 \mathrm{~g}$ for $10 \mathrm{~min}$ at $5^{\circ} \mathrm{C}$. The supernatant contained the remainder of the periplasm (PII fraction). The pellet was suspended in 1 vol. cold distilled water and incubated on ice for at least $30 \mathrm{~min}$. To obtain a complete lysis of the spheroplasts, it was often necessary to subject the spheroplasted cells to sonication or freeze-thawing.

(b)

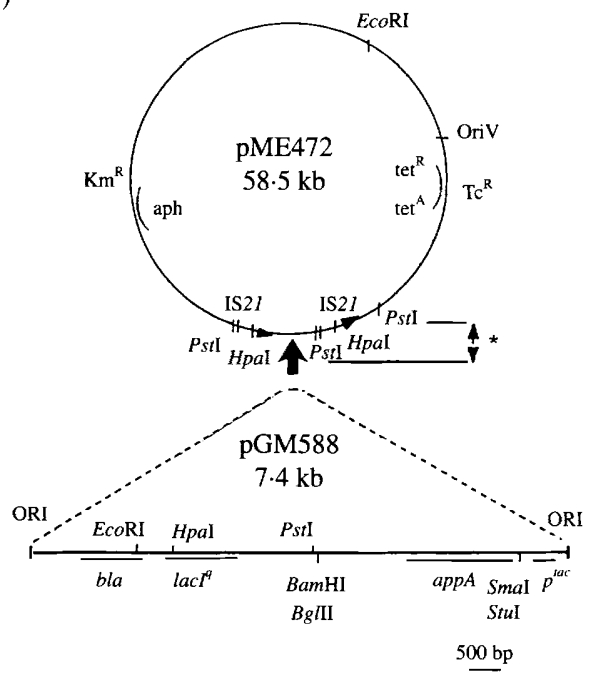

\section{Results}

Construction of $M$. xanthus strain bearing the appA gene under the control of the tac promoter

The app $A$ gene encoding $E$. coli $\mathrm{pH} 2.5$ acid phosphatase was cloned into the polylinker of plasmid pTTQ18 to generate plasmid pGM588 (Fig. 1a); plasmid pTTQ18 contains the $\operatorname{lacl}^{q} p^{t a c}$ system and a polylinker region located downstream of $p^{\text {tac }}$ (Stark, 1987). The E. coli strain DH5 $\alpha$ MCR was transformed with pGM588, and one of the transformants, screened on plate for IPTGinducible $\mathrm{pH} 2.5$ acid phosphatase activity, was retained. The method of Breton \& Guespin-Michel (1987) was used to integrate plasmid pGM588 into the chromosome

Fig. 1. (a) Construction of plasmid pGM588. The StuI, BglII, SmaI and $B a m H I$ digestions and the insert-vector ligation were performed as described in Methods. The $S t u I$ and $S m a I$ restriction enzymes both generate blunt ends, and the $B g / \mathrm{II}$ and $B a m H I$ restriction enzymes

generate compatible cohesive ends. (b) Map of plasmids pGM589 and pGM589*. The asterisk represents a fragment of $6.1 \mathrm{~kb}$ in pGM589 and $5.8 \mathrm{~kb}$ in pGM $589^{*}$ 

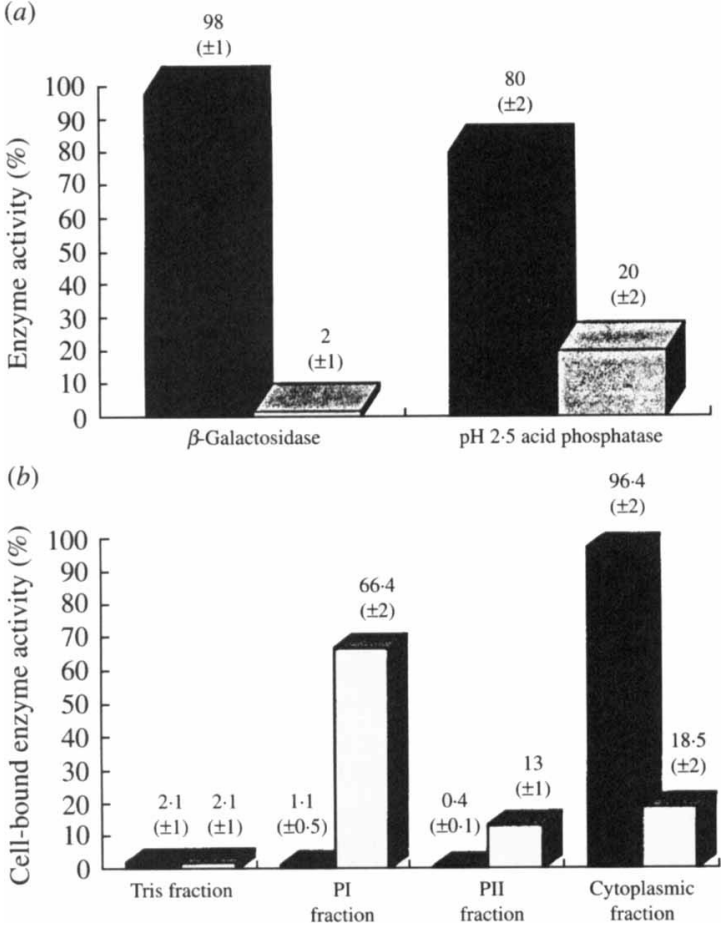

Fig. 2. Localization of $\beta$-galactosidase and $\mathrm{pH} 2.5$ acid phosphatase in the different cell compartments of $M$. xanthus strain CM2216. Cells were grown in CTT medium supplemented with kanamycin $(75 \mu \mathrm{g}$ $\mathrm{ml}^{-1}$ ). The enzyme assays were performed as described in Methods. (a) Extracellular (圆) and cell-bound ( $\mathbf{\square}$ ) activities. Supernatant and cells were separated by centrifugation in a microfuge for $5 \mathrm{~min}$. (b) Distribution of the activities during the different steps of the fractionation procedure. Cell-bound $\beta$-galactosidase activity $(\mathbf{D})$; cellbound $\mathrm{pH} 2.5$ acid phosphatase activity $(\square)$. Cells were fractionated by the procedure described in Methods. The Tris fraction was the washing supernatant; PI fraction containing part of the periplasm was obtained after treatment of the cells by lysozyme-EDTA; PII fraction was the result of a slight osmotic shock which released the remainder of the periplasm; and cytoplasmic fraction was from lysed spheroplasts.

of $M$. xanthus, using a cointegrate between plasmid pGM588 and plasmid pME472 as described in Methods. The resulting cointegrate obtained, pGM589 (Fig. 1b), was transferred by conjugation from $E$. coli to $M$. xanthus strain DZ1. This strain was chosen because it is the best recipient for conjugative plasmids (Breton et al., 1985), it produces low enough amounts of extracellular proteases not to decrease the secreted $\mathrm{pH} 2.5$ acid phosphatase (result not shown), and preliminary studies on the secretion of this foreign protein have been performed with this strain (Breton \& Guespin-Michel, 1987). However, it is a pleiotropic, non-motile, fruitless mutant and it resembles $\mathrm{Exc}^{ \pm}$mutants in its ability to secrete only half the total amount of extracellular proteins secreted by the wild type (Masson \& GuespinMichel, 1988).

One $M$. xanthus transconjugant, designated CM2214, that displayed IPTG-inducibility of app $A$ gene expres- sion, was retained for further studies. The strain was maintained under selective pressure with carbenicillin to stabilize the inserted plasmid pGM588 and oxytetracycline to stabilize the cointegrate (Jaoua et al., 1986). In addition, the number of cells retaining the ability to produce the $\mathrm{pH} 2.5$ acid phosphatase was monitored during each experiment.

\section{Lysis control}

We first checked that secretion was independent of lysis by measuring the appearance in the extracellular medium of both $\beta$-galactosidase and $\mathrm{pH} 2.5$ acid phosphatase when a $M$. xanthus recombinant strain CM2216 (Letouvet-Pawlak, 1991 a) harbouring both the E. coli lac $Z$ and app $A$ genes under the control of the same constitutive promoter, was grown in CTT medium containing kanamycin $\left(75 \mu \mathrm{g} \mathrm{ml}^{-1}\right)$. In this strain, the total specific activity of $\beta$-galactosidase was $152 \pm 2 \mathrm{U}$ ( $\mathrm{mg}$ cell protein $)^{-1}$ and the total specific activity of the acid phosphatase was $148 \pm 3 \mathrm{U}$ (mg cell protein) ${ }^{-1}$. As seen in Fig. 2(a), 20\% of the acid phosphatase but only $2 \%$ of the $\beta$-galactosidase were found in the culture supernatant.

\section{Localization of the cell-bound AppA protein}

This protein is located in the periplasm of its natural host $E$. coli and is processed from a $47 \mathrm{kDa}$ precursor by cleavage of a $2.4 \mathrm{kDa} \mathrm{N}$-terminal signal peptide (Dassa et al., 1990). Localization of the protein in $M$. xanthus was achieved by separation of the different cell compartments by the method of Hartzell \& Kaiser (1991), with the cytoplasmic marker protein $\beta$-galactosidase being used as a control for lysis during cell fractionation. For this purpose, we had to utilize the doubly recombinant strain CM2216 in spite of its enhanced fragility. Protease inhibitors were not required since CM2216 secretes less protease activity than wild type $M$. xanthus strains.

Approximately $80 \%$ of the AppA activity was released with the periplasmic fraction (Fig. $2 b$ ). To avoid lysis of the spheroplasts during the preparation of the periplasmic fraction, we resuspended the pellet after the lysozyme-EDTA treatment in $0 \cdot 1 \mathrm{M}$-sucrose.

The Tris fraction (washing supernatant) contained $2 \cdot 1 \%$ of both activities indicating that only a small fraction of the cells had lysed at this stage (Fig. $2 b$ ).

$\beta$-Galactosidase activity assayed in the total periplasmic fraction (PI + PII; see Methods) was very low ( $1.5 \%$ of the cell-bound activity), while $79.4 \%$ of the pH 2.5 acid phosphatase cell-bound activity was present in this total periplasmic fraction (Fig. 2b). In contrast, $96.4 \%$ of the $\beta$-galactosidase activity and only $18.5 \%$ of the phosphatase activity were detected in the cytoplasmic fraction (obtained by suspending sphero- 

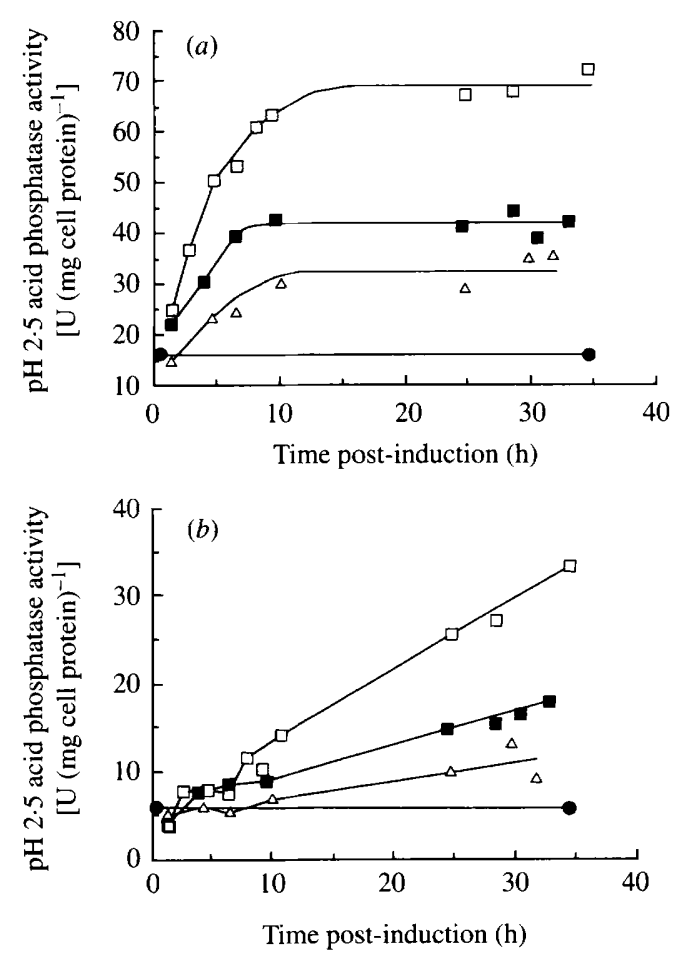

Fig. 3. pH 2.5 acid phosphatase production in cells $(a)$ and supernatant (b) in $M$. xanthus strain CM2214, after IPTG induction during midexponential phase. The $\mathrm{pH} 2.5$ acid phosphatase activity is expressed per mg cell protein. Cells were grown in CTT medium supplemented with oxytetracycline $\left(10 \mu \mathrm{g} \mathrm{ml}^{-1}\right)$ and carbenicillin $\left(250 \mu \mathrm{g} \mathrm{m}^{-1}\right)$ to ensure selective pressure of the cointegrate. IPTG was added at time 0 at final concentrations of $10^{-3} \mathrm{M}(\square), 2 \times 10^{-5} \mathrm{M}(\boldsymbol{\square})$, or $10^{-5} \mathrm{M}(\triangle)$. The $\mathrm{pH} 2.5$ acid phosphatase assays were performed as described in Methods. (a) The activity in uninduced cells (O) was $15 \cdot 1 \mathrm{U}$ AppA (mg cell protein $)^{-1}$. (b) The activity in the supernatant of uninduced cells (C) was $5.4 \mathrm{U}$ AppA (mg cell protein) ${ }^{-1}$.

plasts in cold water) (Fig. 2b). The latter figure is over estimated, however, since the cytoplasmic fraction is contaminated with 5 to $6 \%$ of intact cells. Therefore, we conclude that the cell-bound acid phosphatase activity is located in the periplasm.

\section{Kinetics of AppA accumulation in the periplasm and extracellular medium of $M$. xanthus DZ1 recombinant strain CM2214}

Exponentially growing cells of strain CM2214 were supplemented by IPTG, and $\mathrm{pH} 2.5$ acid phosphatase was assayed in the cells (Fig. $3 a$ ) and supernatant (Fig. $3 b$ ) at different times after induction. The means of repeated experiments are reported in Table 2.

Previous studies on the $\operatorname{lacI}^{q} p^{\text {tac }}$-lac $Z$ system in $M$. xanthus had shown that the level of induction increased in a sigmoidal fashion with IPTG concentration (Letouvet-Pawlak et al., 1990); accordingly, we used three different IPTG concentrations: $10^{-3} \mathrm{M}, 2 \times 10^{-5} \mathrm{M}$ and $10^{-5} \mathrm{M}$.
Table 2. Distribution of pH 2.5 acid phosphatase activity in the cells and enzyme accumulation in the supernatant after induction of $M$. xanthus strain CM2214 with different concentrations of IPTG

Results are the mean of 3-5 experiments. The slope of the accumulation curve was estimated by linear regression $(r=$ correlation coefficient). These results take into account the instability of strain CM2214: we used a correction coefficient calculated by comparison of the levels of activity in uninduced cells obtained in the different experiments.

\begin{tabular}{|c|c|c|}
\hline $\begin{array}{l}\text { IPTG concn } \\
\text { (M) }\end{array}$ & $\begin{array}{l}\mathrm{pH} 2.5 \text { acid } \\
\text { phosphatase activity in } \\
\text { the recombinant cells } \\
{\left[\mathrm{U}(\mathrm{mg} \text { cell protein })^{-1}\right]}\end{array}$ & $\begin{array}{l}\text { Slope of the accumulation } \\
\text { of acid phosphatase in } \\
\text { the supernatant as a } \\
\text { function of time } \\
\left.[\mathrm{U} \text { (mg cell protein })^{-1} \mathrm{~h}^{-1}\right]\end{array}$ \\
\hline $10^{-3}$ & $71 \cdot 1 \pm 12$ & $\begin{array}{r}0.7 \pm 0.15 \\
(r \geqslant 0.986)\end{array}$ \\
\hline $2 \times 10^{-5}$ & $42 \cdot 9 \pm 3 \cdot 5$ & $\begin{array}{l}0.35 \pm 0.05 \\
(r \geqslant 0.964)\end{array}$ \\
\hline $10^{-5}$ & $29 \cdot 8 \pm 3$ & $\begin{array}{l}0.23 \pm 0.02 \\
(r \geqslant 0.926)\end{array}$ \\
\hline 0 & $14 \cdot 6 \pm 1$ & - \\
\hline
\end{tabular}

Cell-bound $\mathrm{pH} 2.5$ acid phosphatase accumulation was very similar to that obtained with $\beta$-galactosidase when the lac $Z$ gene was expressed in $M$. xanthus under the control of $p^{t a c}$ (Letouvet-Pawlak et al., 1990). The increase of the specific activity over the uninduced background was dependent on IPTG concentration; $\mathrm{pH} 2.5$ acid phosphatase started accumulating in the cells less than $1 \mathrm{~h}$ after induction with $10^{-3} \mathrm{M}$ and $2 \times 10^{-5} \mathrm{M}-$ IPTG, and $2 \mathrm{~h}$ after induction with $10^{-5} \mathrm{M}$-IPTG. No decrease of specific activity was found until $53 \mathrm{~h}$ after induction.

pH 2.5 acid phosphatase secretion (Fig. $3 b$ ) is expressed as the ratio of the extracellular activity to the cell protein content. Three phases can be described: phase 1 corresponds to a retention of the enzyme in the cells; phase 2 corresponds to a linear increase of the extracellular phosphatase activity per $\mathrm{mg}$ of cell protein, the slope of which is roughly proportional to the maximal specific activity of the cell-bound enzyme (Table 2); the third phase is reached $30-45 \mathrm{~h}$ after IPTG induction and corresponds to a steady state: the extracellular activity is then equal to $28 \pm 2 \%$ of the total activity. The proteolytic activity produced in the medium was assayed. No difference could be observed with or without IPTG, suggesting that induction of $\mathrm{pH} 2.5$ acid phosphatase production and secretion of the enzyme did not disturb the overall secretory mechanism.

\section{Probing secretion in other strains}

New strains were constructed in a continuation of the study. A mating was performed between strain CM2214 


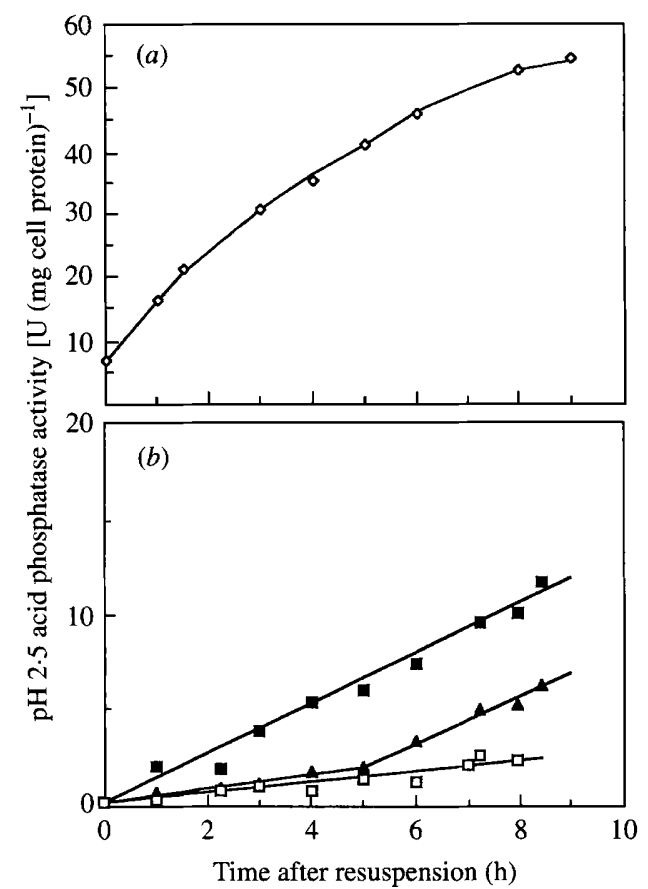

Fig. 4. pH 2.5 acid phosphatase production in cells $(a)$ and supernatant of cultures $(b)$ of $M$. xanthus strain CM2217 after resuspension of growing cells in fresh CTT medium. The resuspension medium was supplemented with oxytetracycline as the culture medium. The $\mathrm{pH} 2 \cdot 5$ acid phosphatase activity is expressed per $\mathrm{mg}$ cell protein. This activity was assayed as described in Methods. (a) Accumulation of cell-bound specific activity in non-induced cells resuspended in CTT plus $10^{-3} \mathrm{M}-$ IPTG. (b) Activity in the supernatant. ( $\square$ ) Non-induced cells resuspended in CTT minus IPTG; $(\boldsymbol{A})$ non-induced cells resuspended in CTT plus $10^{-3} \mathrm{M}$-IPTG; ( $\boldsymbol{\square}$ ) induced cells resuspended in CTT plus $10^{-3} \mathrm{M}$-IPTG (i.e. in fully induced conditions).

(DZ1::pGM589) as donor and E. coli W3101 Nal as recipient. Jaoua et al. (1990) have shown that the integration of the IncP plasmid RP4 (Datta et al., 1971) in the chromosome of $M$. xanthus is followed by different DNA rearrangements. Modified plasmids, called RP4*, may be obtained upon conjugation with $E$. coli and display a higher frequency of integration when transferred back to $M$. xanthus (HFI plasmids). This proved to hold true with RP4 derivatives such as the cointegrate pGM589, since the retransferred cointegrate pGM589* was shown to possess all the characteristics of pGM589, but was transferable to $M$. xanthus strains with a much higher frequency $\left(1.5 \times 10^{-5}\right.$ when the recipient strain was DK101 instead of $10^{-7}$ for pGM589) and was more stably maintained. A deletion of $0.3 \mathrm{~kb}$ was observed in the $6.1 \mathrm{~kb} P$ stI restriction fragment of pME472 which was similar to that previously found in HFI plasmids (Jaoua et al., 1990) (Fig. 1b). CM2217 and CM243 are recombinants producing IPTG-inducible acid phosphatase obtained by transferring plasmid pGM589* into strain DZ1 and strain CM240 $\left(\mathrm{Exc}^{+}\right)$, respectively.

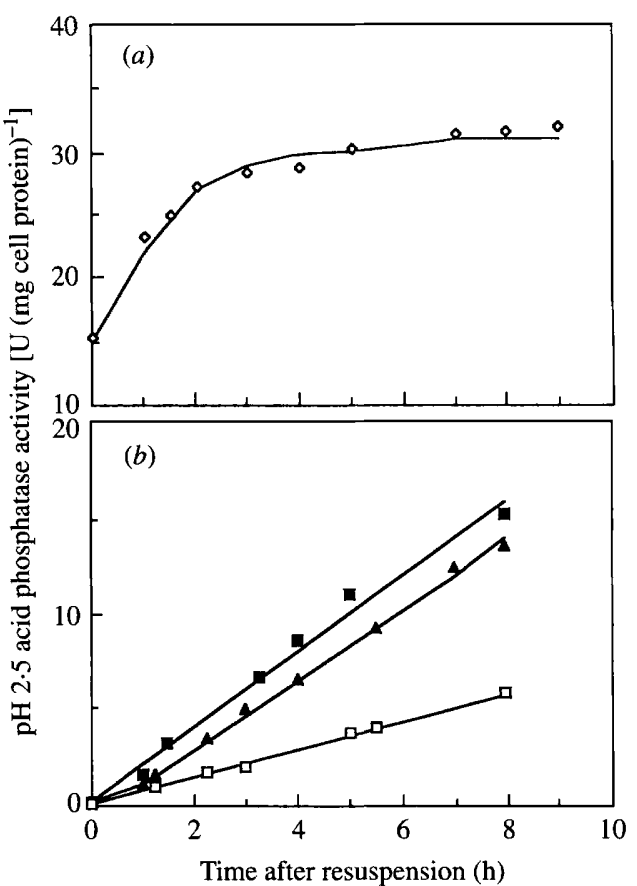

Fig. 5. pH 2.5 acid phosphatase production in cells $(a)$ and supernatant of cultures $(b)$ of $M$. xanthus strain CM243 after resuspension of growing cells in fresh CTT medium. Conditions and symbols are as described in the legend to Fig. 4. (a) Accumulation of cell-bound specific activity in non-induced cells resuspended in CTT plus $10^{-3} \mathrm{M}$ IPTG. (b) Activity in the supernatant.

The experiment described above presents the major drawback that acid phosphatase activity decreases in the supernatant of strains producing wild type levels of proteases. We therefore modified the experimental procedure in order to study AppA secretion under conditions where proteolysis was negligible in all strains. This was achieved by pelleting growing cells and suspending them in fresh CTT medium (devoid of proteases), thus allowing AppA protein secretion to be followed under non-induced conditions (NI), fully induced conditions (I), or when induction was started concomitant with the resuspension.

When these experimental conditions were tested on strain CM2217 (DZ1::pGM589*) it was found that kinetics of appearance of extracellular AppA and cellassociated AppA activity differed upon induction with IPTG. For cells previously induced with IPTG and resuspended in fresh CTT medium containing IPTG, AppA activity in the medium was detected immediately and increased in a linear fashion with the slope of the curve being proportional to the amount of cell-bound AppA present in the cells at the time of resuspension (Fig. 4b). However, when non-induced cells were resuspended in IPTG-supplemented medium the level of AppA secretion remained identical to that of the non- 
Table 3. Comparison of secretion characteristics of three recombinant strains

\begin{tabular}{lccc}
\hline \hline & CM2217 & CM243 & CM245 \\
\hline $\begin{array}{c}\text { Cell-bound AppA specific } \\
\text { activity in non-induced } \\
\text { cells [U (mg cell protein) })^{-1} \text { ] }\end{array}$ & $14 \pm 1$ & $14 \pm 4$ & $8 \cdot 6 \pm 1 \cdot 5$ \\
Cell-bound AppA specific & $88 \cdot 7 \pm 10$ & $30 \pm 5$ & $17 \cdot 7 \pm 5$ \\
activity in fully induced \\
cells [U (mg cell protein) ${ }^{-1}$ ]
\end{tabular}

* NI, Non-induced cells; I, induced cells; $(-)$, resuspension in CTT; $(+)$, resuspension in CTT plus $10^{-3} \mathrm{M}$-IPTG.

$\dagger$ The relative rate of secretion is the ratio 'slope of the secretion curve of AppA/AppA specific activity in the resuspended cells $\times 100$ '.

$\ddagger$ The retention time is the time during which the slope of the secretion curve obtained upon IPTG induction is identical to that obtained in non-induced conditions.

induced cells for about $5 \mathrm{~h}$, and then increased (Fig. $4 \mathrm{~b}$ ), in contrast to the level of periplasmic AppA activity which increased $1 \mathrm{~h}$ after resuspension (Fig. $4 a$ ). This defines a retention time of about $5 \mathrm{~h}$, as previously demonstrated, as well as a linear increase of extracellular AppA production.

When the same experiment was performed with strain CM243 (Fig. 5), the overall kinetics were similar. AppA accumulation in cells after induction started to occur in less than $1 \mathrm{~h}$ and reached a plateau corresponding to the fully induced level. The curves of extracellular AppA secretion were linear and their slopes were proportional to the periplasmic AppA concentration at the time of resuspension. However several differences between strains CM243 and CM2217 were observed (Table 3): (i) the levels of cell-bound activities were different; (ii) the relative secretion rate, defined as the ratio 'slope of secretion curve/periplasmic AppA specific activity' - a constant for induced and non-induced conditions, was higher in strain CM243; (iii) the retention time was less than $1 \mathrm{~h}$ in strain CM243. The significance of these discrepancies is not clear however, since the parental strains DK1622 and DZ1 may differ in several characteristics, and the location of the inserted pGM589* may also be different in strains CM2217 and CM243 (Breton et al., 1985; Breton \& Guespin-Michel, 1987; Jaoua et al., 1990). A significant comparison between the phenotypes $\mathrm{Exc}^{+}$and $\mathrm{Exc}^{ \pm}$requires isogenic strains that

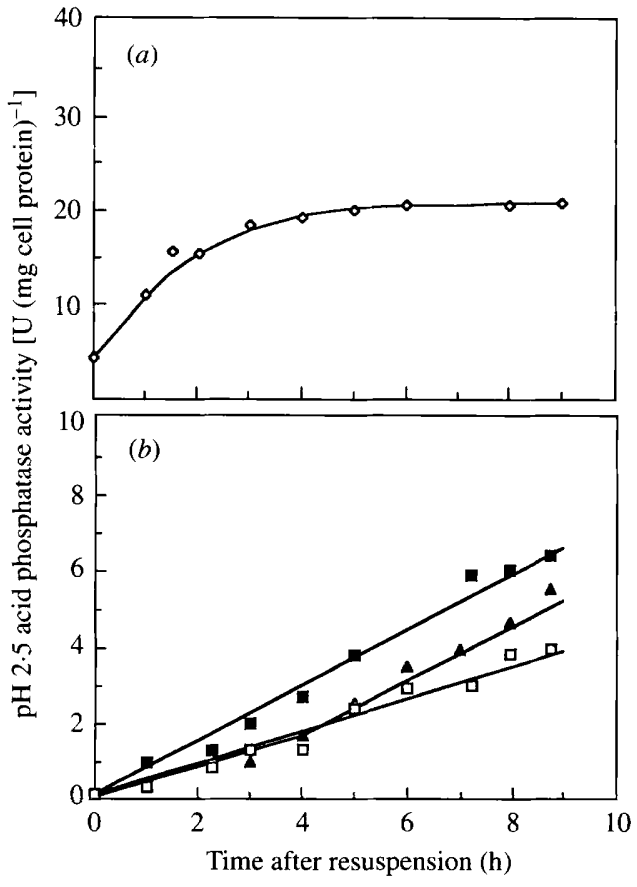

Fig. 6. $\mathrm{pH} 2.5$ acid phosphatase production in cells $(a)$ and supernatant of cultures $(b)$ of $M$. xanthus strain CM245 after resuspension of growing cells in fresh CTT medium. Conditions and symbols are as described in the legend to Fig. 4. (a) Accumulation of cell-bound specific activity in non-induced cells resuspended in CTT plus $10^{-3} \mathrm{M}$ IPTG. (b) Activity in the supernatant.

differ only in their overall ability to secrete native proteins.

Strain CM031 is an Exc \pm Tn5 insertion mutant of strain DK101 (Nicaud et al., 1984). Petit et al. (1993) showed that the $\operatorname{Exc}^{ \pm}$phenotype can be transduced along with the Tn5 insertion $(\Omega 031)$ into strain DK 1622 . Similarly, strain CM245 is an Exc ${ }^{ \pm}$CM243::Tn5 $\Omega 031$ strain constructed by $\mathrm{Mx}^{\text {ts }}$ transduction. Fig. 6 shows that strain CM245 displays an AppA protein secretion pattern different from that obtained with the parental strain CM243, but rather similar to that obtained with strain CM2217, i.e. a retention time of 5-6 h (although cell-bound accumulation begins less than $1 \mathrm{~h}$ after induction) and a slope of the secretion curve that is less steep than that obtained with CM243. In addition, the total production of AppA was nearly twofold lower in CM245 compared with CM243 for both induced and non-induced cultures.

Table 3 summarizes these results. Two parameters may be used to characterize AppA protein secretion: the retention time which is much shorter in the $\mathrm{Exc}^{+}$strain, and the relative rate of secretion which is independent of the specific activity of the cells, different in all three strains, and higher in the Exc ${ }^{+}$strain. The cell-bound specific activity in both induced and non-induced cells is also a relevant parameter since it is reduced in the Exc ${ }^{ \pm}$ 
CM245 recombinant relative to the $\mathrm{Exc}^{+}$parental strain CM243.

\section{Discussion}

The fact that the $E$. coli periplasmic $\mathrm{pH} 2.5$ acid phosphatase, when expressed in $M$. xanthus from its gene inserted into the host chromosome, is partially secreted and partially cell-bound, in contrast to native extracellular proteins that are fully secreted, has enabled us to construct a probe to analyse the two steps of the protein secretion mechanism in $M$. xanthus.

We have shown that this secretion is not due to cell lysis and that the cell-bound acid phosphatase is mainly, if not totally, located in the periplasm of the recombinant $M$. xanthus cells. Therefore the production of extracellular AppA reflects the translocation of the protein through the outer envelope.

We made use of these properties to construct a probe consisting of a transferable cointegrate able to be inserted at random in the $M$. xanthus chromosome, in which the appA gene is under the control of the inducible tac promoter. This construct was first inserted in strain DZ1. Extracellular AppA is not degraded in the culture supernatant from this strain, and the kinetics of production and secretion of this protein can be followed over several generations until the steady state is reached.

The kinetics of export of acid phosphatase are more rapid than those of secretion, which is characterized by an interval during which the protein accumulated in the periplasm is not released into the medium (the retention time) and by the fact that extracellular AppA accumulation expressed per $\mathrm{mg}$ of cell protein increases linearly (for $30-45 \mathrm{~h}$ ) with a slope that depends on the amount of cell-bound phosphatase.

These results could be explained if protein diffusion through the periplasmic gel and/or the outer membrane was the limiting step of the secretion process. The initial stage of enzyme retention in the cells preceding secretion would therefore correspond to the time required for its diffusion through one and/or the other of these structures, and the percentage of enzyme released into the extracellular medium would depend on its diffusion coefficient.

The existence of a periplasmic gel has been proposed by Kellenberger (1990); thus, in M. xanthus, the proteins could diffuse in this gel with a specific diffusion coefficient dependent on their size, conformation and charge, to the inner side of the outer membrane, before crossing this membrane. Diffusion could also be the translocation mechanism through the outer membrane. Baty et al. (1987) proposed that colicin A could reach the extracellular medium in E. coli by slow diffusion of the protein through the inner and outer membranes, after an increase in the permeability of these membranes due to the action of the lysis protein.

When the kinetics were studied for a shorter time with cells resuspended in fresh CTT, essentially the same results are obtained. The slopes of the curve of accumulation of extracellular AppA reflect the secretion rates; thus, the ratio 'slope of the curve/periplasmic AppA specific activity' was referred to as the 'relative rate of secretion' which is independent of the cell-bound specific activity.

Can results obtained with a foreign protein, chosen because it was secreted less efficiently by $M$. xanthus than the native proteins, be of biological significance with regard to the mechanism of secretion of these native proteins? It is comparison of results obtained with CM243 and CM245, isogenic recombinant strains that differ by a single Exc ${ }^{ \pm}$mutation, which gives credit to the method, since this mutation impairs the secretion of most native proteins (Petit et al., 1993).

The relative rate of secretion is higher in the $\mathrm{Exc}^{+}$ recombinant. In this strain the retention time, if any, is less than $1 \mathrm{~h}$, whereas it is 5-6 $\mathrm{h}$ in the Exc ${ }^{ \pm}$mutant and also in strain DZ1 which behaves as an Exc ${ }^{ \pm}$mutant. Thus, the Exc ${ }^{ \pm}$mutation introduced in the wild type recombinant modifies the permeability properties of the envelopes toward AppA protein. In addition, this mutation also decreases the amount of accumulated periplasmic AppA. This may be due to increased degradation of this protein during the long retention time, or it may reflect a coupling between export and secretion, which would represent another peculiarity of the secretory mechanism in $M$. xanthus.

Since the overall effect of the $\mathrm{Exc}^{ \pm}$mutation on native protein secretion is the same as that observed with protein AppA, it is likely that native proteins are secreted by the same route as this foreign protein, although their structure would allow a more efficient diffusion.

Regardless of the actual mechanism, our method has allowed the definition of two parameters (retention time and relative secretion rate of the AppA protein) that characterize the permeability and hence the structure of the envelopes of different strains of $M$. xanthus. These parameters should aid in the analysis of different $\mathrm{Exc}^{ \pm}$ mutations (which are also unable to undergo development in response to nutrient starvation) and the monitoring of possible changes in membrane permeability during development in the wild type strain.

We thank Dr C. Lazdunski and Professor C. Ripoll for stimulating discussions and Dr P. L. Boquet for helpful advice and the gifts of plasmids.

\section{References}

Andro, T., Chambost, J. P., Kotoujansky, A., Cattaneo, J., Bertheau, Y., Barras, F., Van Giusegem, F. \& Coleno, A. (1984). 
Mutants of Erwinia chrysanthemi defective in secretion of pectinase. Journal of Bacteriology 160, 1199-1203.

APPLEYARD, R. K. (1954). Segregation of new lysogenic types during growth of a doubly lysogenic strain derived from Escherichia coli K12. Genetics 39, 440-452.

Baty, D., Lloubes, R., Geli, V., Lazdunski, C. \& Howard, S. P. (1987). Extracellular release of colicin A is non-specific. EMBO Journal 6, 2463-2468.

BiRnboim, H. C. \& Doly, J. (1979). A rapid alkaline extraction procedure for screening recombinant plasmid DNA. Nucleic Acids Research 7, 1513-1523.

Boquet, P. L., Manoil, C. \& Beckwith, J. (1987). Use of TnphoA to detect genes for exported proteins in Escherichia coli: identification of the plasmid-encoded gene for a periplasmic acid phosphatase. Journal of Bacteriology 169, 1663-1669.

Breton, A. \& Guespin-Michel, J. F. (1987). E. coli pH 2.5 acid phosphatase and $\beta$-lactamase TEM-2 are secreted into the medium by Myxococcus xanthus. FEMS Microbiology Letters 40, 183-188.

Breton, A. M., Jaoua, S. \& Guespin-Michel, J. F. (1985). Transfer of plasmid RP4 to Myxococcus xanthus and evidence for its integration into the chromosome. Journal of Bacteriology 161, 523-528.

Breton, A. M., Younes, G., Van Gijsegen, F. \& Guespin-Michel, J. F. (1986). Expression in Myxococcus xanthus of foreign genes coding for secreted pectate lyases of Erwinia chrysanthemi. Journal of Biotechnology 4, 303-311.

Breton, A. M., Buon, 1. \& Guespin-Michel, J. F. (1990). Use of TnphoA to tag exported proteins in Myxococcus xanthus. FEMS Microbiology Letters 67, 179-186.

BRETSCHER, A. P. \& KAISER, D. (1978). Nutrition of Myxococcus xanthus, a fruiting myxobacterium. Journal of Bacteriology 133, 763-768.

Campos, J. M., Geiselsoder, J. \& Zusman, D. (1978). Isolation of bacteriophage $\mathrm{Mx4}$, a generalized transducing phage for Myxococcus xanthus. Journal of Molecular Biology 119, 167-178.

DagerT, M. \& Ehrlich, S. D. (1974). Prolonged incubation in calcium chloride improves competence of Escherichia coli cells. Gene $\mathbf{6}$, 23-28.

Dassa, E. \& Boquet, P. L. (1981). ExpA: a conditional mutation affecting the expression of a group of exported proteins in Escherichia coli K-12. Molecular and General Genetics 181, 192-200.

DASSA, E. \& BOQUET, P. L. (1985). Identification of the gene appA for the acid phosphatase (pH optimum 2.5) of Escherichia coli. Molecular and General Genetics 200, 68-73.

DasSa, J., Marck, C. \& BoqueT, P. L. (1990). The complete nucleotide sequence of the Escherichia coli gene appA reveals significant homology between $\mathrm{pH} 2.5$ acid phosphatase and glucose-1-phosphatase. Journal of Bacteriology 172, 5497-5500.

Datta, N., Hedges, R. W., Shaw, E. J., Sykes, R. B. \& Richmond, M. H. (1971). Properties of an $\mathrm{R}$ factor from Pseudomonas aeruginosa. Journal of Bacteriology 108, 1244-1249.

Hanahan, D. (1983). Studies on transformation of Escherichia coli with plasmids. Journal of Molecular Biology 166, 557-580.

HaRTZELl, P. \& KaISER, D. (1991). Function of MglA, a 22-kilodalton protein essential for gliding in Myxococcus xanthus. Journal of Bacteriology 173, 7615-7624.

He, S. Y., Lindeberg, M., Chatterjee, A. K. \& Collmer, A. (1991). Cloned Erwinia chrysanthemi out genes enable Escherichia coli to selectively secrete a diverse family of heterologous proteins to its milieu. Proceedings of the National Academy of Sciences of the United States of America 88, 1079-1083.

HiRST, T. R. \& WELCH, R. A. (1988). Mechanisms for secretion of extracellular proteins by Gram-negative bacteria. Trends in Biochemical Sciences 13, 265-269.

Hodgkin, J. \& KaISER, D. (1979). Genetics of gliding motility in Myxococcus xanthus (Myxobacterales): genes controlling movement of single cells. Molecular and General Genetics 171, 167-176.

Holmes, D. S. \& Quigley, M. (1981). A rapid boiling method for the preparation of bacterial plasmids. Analytical Biochemistry 114, 193-197.
Howard, S. P. \& BuCKLEY, J. T. (1983). Intracellular accumulation of extracellular proteins by pleiotropic export mutants of Aeromonas hydrophila. Journal of Bacteriology 154, 413-418.

Jaoua, S., Breton, A. M., Younes, G. \& Guespin-Michel, J. F. (1986). Structural instability and stabilization of IncP-1 plasmids integrated into the chromosome of Myxococcus xanthus. Journal of Biotechnology 4, 313-323.

JaOua, S., Letouvet-Pawlak, B., Monnier, C. \& Guespin-Michel, J. F. (1990). Mechanism of integration of the broad host range plasmid RP4 into the chromosome of Myxococcus xanthus. Plasmid 23, 183-193.

KAISER, D. (1979). Social gliding is correlated with the presence of pili in Myxococcus xanthus. Proceedings of the National Academy of Sciences of the United States of America 76, 5952-5956.

Kalos, M. \& Zissler, J. (1990). Transposon tagging of genes for cell-cell interactions in Myxococcus xanthus. Proceedings of the National Academy of Sciences of the United States of America 87, $8316-8320$

KeLLENBERGER, E. (1990). The 'Bayer bridges' confronted with results from improved electron microscopy methods. Molecular Microbiology 4, 697-705.

Kopecko, D. J., BREvet, J. \& COHEN, S. N. (1976). Involvement of multiple translocating DNA segments and recombinational hotspots in the structural evolution of bacterial plasmids. Journal of Molecular Biology 108, 333-360.

LetouVET-PaWlaK, B. (1991a). Mécanisme de sécrétion des protéines chez Myxococcus xanthus: étude de la sécrétion d'une protéine étrangère après clonage du gène en aval d'un promoteur inductible. Thèse de Doctorat, Université de Rouen (France).

LeTOUVET-PAWLAK, B. (1991 $b$ ). La sécrétion des protéines chez les bactéries à Gram négatif. Annales de l'Institut Pasteur/actualités 4, 290-309.

Letouvet-Pawlak, B., Monnier, C., Barray, S., Hodgson, D. A. \& Guespin-Michel, J. F. (1990). Comparison of $\beta$-galactosidase production by two inducible promoters in Myxococcus xanthus. Research in Microbiology 141, 425-435.

MANOIL, C. \& BECKwITH, J. (1985). TnphoA: a transposon probe for protein export signals. Proceedings of the National Academy of Sciences of the United States of America 82, 8129-8133.

MASSON, P. J. \& GueSPIN-MicheL, J. F. (1988). An extracellular bloodanticoagulant glycopeptide produced exclusively during vegetative growth by Myxococcus xanthus and other myxobacteria is not coregulated with other extracellular macromolecules. Journal of General Microbiology 134, 801-806.

Miller, J. H. (1972). Experiments in Molecular Genetics. Cold Spring Harbor, NY: Cold Spring Harbor Laboratory.

Millet, J. (1970). Characterization of proteinases excreted by Bacillus subtilis Marburg strain during sporulation. Journal of Applied Bacteriology 33, 207-219.

Nicaud, J. M., Breton, A., Younes, G. \& Guespin-Michel, J. F. (1984). Mutants of Myxococcus xanthus impaired in protein secretion: an approach to study of a secretory mechanism. Applied Microbiology and Biotechnology 20, 344-350.

Petit, F., Merah, M., Monnier, C. \& Guespin-Michel, J. F. (1993). Mutations in two new loci that impair both extracellular protein production and development in Myxococcus xanthus. Journal of Bacteriology 175, 4239-4244.

Pugsley, A. P. (1988). Protein secretion across the outer membrane of Gram-negative bacteria. In Protein Transfer and Organelle Biogenesis, pp. 607-652. Edited by R. A. Das \& P. W. Robbins. London: Academic Press.

Pugsley, A. P. (1993). The complete general secretory pathway in Gram-negative bacteria. Microbiological Reviews 57, 50-108.

Reimmann, C., Rella, M. \& HaAs, D. (1988). Integration of replication-defective R68.45-like plasmids into the Pseudomonas aeruginosa chromosome. Journal of General Microbiology 134, 1515-1523.

RosenberG, E. \& VARON, M. (1984). Antibiotics and lytic enzymes. In Myxobacteria. Development and Cell Interactions, pp. 109-125. Edited by E. Rosenberg. New York, Berlin, Heidelberg, Tokyo: Springer-Verlag.

Saulnier, P., Hanquier, J., Jaoua, S., Reichenbach, H. \& Guespin- 
Michel, J. F. (1988). Utilization of Inc P1 plasmids as vectors for transposon mutagenesis in Myxobacteria. Journal of General Microbiology 134, 2889-2895.

SHImkETS, L. J. (1989). The role of the cell surface in social and adventurous behaviour of myxobacteria. Molecular Microbiology 3 , $1295-1298$.

STARK, M. J. R. (1987). Multicopy expression vectors carrying the lac repressor gene for regulated high-level expression of genes in Escherichia coli. Gene 51, 255-267.

Thurn, K. K. \& ChatterJee, A. K. (1985). Single-site chromosomal
$\mathrm{Tn} 5$ insertions affect the export of pectolytic and cellulolytic enzymes in Erwinia chrysanthemi EC16. Applied and Environmental Microbiology 6, 894-898.

WretLind, B. \& Pavlovskis, O. R. (1984). Genetic mapping and characterization of Pseudomonas aeruginosa mutants defective in the formation of extracellular proteins. Journal of Bacteriology $\mathbf{1 5 8}$, 801-808.

Zusman, D. R., Krotoski, D. M. \& Cumsky, M. (1978). Chromosome replication in Myxococcus xanthus. Journal of Bacteriology 133 122-129. 